Walisongo Law Review (Walrev), Vol 2 No. 2 (2020)

DOI: 10.21580/Walrev/2020.2.2.6588

Copyright (C) 2020 Walisongo Law Review (Walrev)

\title{
The Concept of Death Penalty in a Pancasila State (Perspective of Official Religion in Indonesia)
}

\author{
Maria Anna Muryani, Noor Rosyidah
}

Afiliasi: Universitas Islam Negeri (UIN) Walisongo, Semarang

Email: rosyi.noor@walisongo.ac.id

\begin{abstract}
The death penalty concept in perspective the official religion in Indonesia is an issue that is worthy of study in line wiht the execution of drug convicts lately. MUI fatwa No.10/Munas VII/MUI/ 14/2005 on the death penalty in a Specific Crime allow the penalty in certain types of criminal acts. In a latter sent to his congregation, paul chapter 13 yat 1-4 mention about the goverment's authority to impose penalties for offenders. St. Agustine and Thomas Aquinas assume that the state, in order to achieve common prosperity, can performthe death penalty. St. Agustine assess the death penalty as a way to prevent crime and protect those who are innocent. Buton the other hand the human right activists who joined in contrast, Impartial and Elsam reject the death penalty and the Roman catholic Church and Christians argue that the death penalty should not be carried out because it violates basic human right, namely the righ to life. Therefore, research is the theme of the death penalty in the perspective of the official state religions in the frame Pancasila want to investigate this further on the death
\end{abstract}


penalty in the perspective of religion are officially recognized by the state as defined in the following issues; How does the concept of the death penalty in perspective official religions in Indonesia are contained in their holy book? And How the concept of the death penalty to be reviewed from the perspective of the state ideology Pancasila? This research is a normative juridical or doctrinal research. This study uses several approaches that approach to the concept (conceptual approach), approach to the comparative (comparative approach) and approach to legislation (statute approach). This study was a descriptive analytical method of data collection in the form of a data library (library research) and interviews.

Konsep hukuman mati dalam perspektif agama resmi di Indonesia merupakan sebuah isu yang patut dikaji sejalan dengan pelaksanaan eksekusi mati narapidana narkoba. Fatwa MUI No.10/Munas VII/MUI/14/2005 tentang pidana mati dalam Tindak Pidana Tertentu memungkinkan adanya pidana dalam jenis tindak pidana tertentu. Dalam surat terakhir yang dikirim ke jemaahnya, pasal 13 ayat 14 menyebutkan tentang kewenangan pemerintah untuk menjatuhkan sanksi bagi pelanggar. St Agustine dan Thomas Aquinas beranggapan bahwa negara, untuk mencapai kesejahteraan bersama, dapat melaksanakan hukuman mati. St Agustine menilai hukuman mati sebagai cara untuk mencegah kejahatan dan melindungi mereka yang tidak bersalah. Namun di sisi lain para aktivis HAM yang bergabung sebaliknya, Imparsial dan Elsam menolak hukuman mati dan Gereja Katolik Roma dan Kristen berpendapat bahwa hukuman mati tidak boleh dilakukan karena melanggar hak asasi manusia, yaitu hak untuk hidup. Oleh karena itu, penelitian yang mengangkat tema pidana mati dalam perspektif agama resmi negara dalam bingkai Pancasila ingin diteliti lebih jauh mengenai hukuman mati dalam perspektif agama yang diakui secara resmi oleh negara sebagaimana dirumuskan dalam isu-isu berikut; Bagaimana konsep hukuman mati dalam perspektif agama-agama resmi di Indonesia yang dimuat dalam kitab sucinya? Dan Bagaimana konsep hukuman mati ditinjau dari perspektif ideologi negara Pancasila? Penelitian ini merupakan penelitian yuridis normatif atau 
penelitian doktrinal. Penelitian ini menggunakan beberapa pendekatan yaitu pendekatan konsep (conceptual approach), pendekatan komparatif (comparative approach) dan pendekatan perundang-undangan (statute approach). Penelitian ini merupakan metode pengumpulan data deskriptif analitik berupa pustaka data (studi pustaka) dan wawancara.

Keywords: Death Penalty; Official Religion; Pancasila.

\section{Introduction}

The concept of the death penalty is still the focus of news in both national and international mass media along with the execution of the death penalty for narcotics crimes (Siswanto 2009). Indonesia is one of the few countries in the world that still imposes the death penalthy. On January 18, 2015, the government executed 6 death convicts, the majority of whom were related to narcotics crimes from several death convicts, but based on the prosecutor's data, in 2014 there were 148 people sentenced to death from 3 types of cases, namely drugs, murder and terrorism (Kompas, 29 November 2014). In 2009-2013, the number of convicted death convicts was dominated by narcotics cases, which reached 313 people; the second place was convicted of murder cases, namely 298 people, while terrorism cases were recorded as 2 convicts, so that within 5 years (2009-2013) the number of death row convicts was recorded as 613 people. If divided annually there are 123 people, while in 2014 there were 148 people. Based on these data, it can be interpreted that the death penalty does not reduce crime and its implementation merely increases the number of deaths in Indonesia.

Based on the record of international amnesty, the implementation of the death penalty in Indonesia when compared to countries that still impose death penalty, Indonesia is not included in the top five. China is the country with the most death sentences, in 2012 China executed 2000 people, second place was Iran with 314 executions and third was Iraq by executing 129 people, and the fourth Saudi Arabia executed 79 people and the United States as the fifth 
country to execute 46 people on the same year. This number has increased in 2013; Amnesty International noted the execution of the death penalty increased by $15 \%$ compared to 2012. Germany Deutsche Well launched in 2013 China as the country with the highest number of executions with 2400 prisoners dying, Iran 369 died through executions, Iraq executed 169 people, Saudi Arabia 79 people and 3 of them were under 18 years old, the last time the United States executed 39 prisoners using poison injections.

With the increase in the execution of the death penalty, there are questions that question the existence of the death penalty. Human Rights (HAM) activists have the view that the death penalty is a form of violation of human rights because the right to life of every human being cannot be revoked by law or other human beings (Gilessen 2005; Prakoso and Nurwachid 1984). According to human rights defenders, the dynamics of criminal law has shifted from the theory of retaliation to the theory of rehabilitation which is clinical treatment. Human rights activists argue that the application of the death penalty can be classified as a cruel and inhuman form of punishment, as stated in article 3 of the Universal Declaration of Human Rights which reads: "Everyone has the right to life, freedom and safety as an individual." This guarantee is confirmed in article 6 paragraph (1) and article (7) of the International Covenant on Civil and Political Rights (ICCPR) and strengthened by the 1989 International Covenant on Civil and Political Rights concerning the Abolition of the Death Penalty. Therefore the death penalty basically contradicts humanitarian principles and must be eliminated or abolished.

Although human rights activists who joined Kontras, Imparsial, and Elsam rejected the death penalty, Komnas HAM Commissioner for the period 2012-2017 Manager Nasution agreed that the death penalty was enforced in Indonesia. According to him, there are 3 facts that support the imposition of the death penalty in Indonesia. First, the philosophical-sociological facts: The death penalty is indeed the most severe punishment imposed on perpetrators of serious crimes and involves various authorities and interests and is related to fair and civilized human values. Based on the conditions of society and 
the state that require law enforcement and public order, there needs to be an attitude towards the death penalty in certain crimes to serve as guidelines. Second, the juridical facts, the existence of laws and regulations that bind all citizens that regulate crimes punishable by death, including: crimes against the nation-state (article 104,111 paragraph \{2\}, 124 paragraph $\{3\}$ and 140 paragraph $\{3\}$ KUHP), premeditated murder (article 340 KUHP) (Septiawan 2020; Zakaria 2020). In addition, the Law on Narcotics and Psychotropic Drugs and Law No.1 of 2002 concerning the Eradication of Criminal Acts of Terrorism also include the threat of the death penalty.

Those who reject the death penalty give several considerations to reject the death penalty as a type of crime or criminal sanction as follows: First, the death penalty is currently unable to fulfill the demands of a sense of justice in modern society because it leaves a person's life and death decisions to a judge who does not escape. from mistakes. Second, the death penalty is not always effective as an effort to prevent or deter people from committing crimes. Third, on the basis of humanitarian considerations, the death penalty violates human rights values, which blocks the opportunity for a convict to improve himself (Salmi 1985:99). Whereas, those who agree with the institutionalization of the death penalty in Indonesia argue that the death penalty has a higher effective rate than other punishments because it has a frightening effect (shock therapy) and is more economical. The death penalty is used so that there is no eigenrichting in society. Theoretically, the death penalty will also have a deterrent effect which is very high, so that it will cause people to discourage their intention to commit a criminal act, so that it can be used as a good tool for general and special prevention (Arief 2005; Hapsin 2017; Salmi 1985:127).

The issue of the death penalty is not only a social problem as well as a legal problem, but also one of the concerns of religious circles. MUI Fatwa No.10/MunasVII/MUI/14/2005 concerning Death Penalty in Certain Crimes. The fatwa allows the death penalty in certain types of criminal acts. In a letter sent to his congregation, Paulus chapter 13 verses 1-4 mentions the government's authority to 
impose punishment for criminals. St Augustine and Thomas Aquinas considered that the state in order to achieve common prosperity could carry out the death penalty. St. Augustine saw the death penalty as a means of preventing crime and protecting innocent parties. While, Thomas Aquinas emphasized that the state is not only entitled but also its duty to protect its citizens from enemies of the state, both from within and from outside (Darsono 2006; Nawawi Arief 2009).

Based on the background of the above problems, research on the death penalty in the Pancasila state from the perspective of official religions would further examine the death penalty from a religious perspective recognized by the state by formulating the following problems: what is the concept of the deth penalty in the perspective of religions recognized in Indonesia as stated in their holy book? And How is the concept of the death penalty viewed from the basic perspective of the Pancasila state?

\section{Death Penalty in the Perspective of Official Religion in Indonesia}

\section{Death Penalty in Islamic Perspective}

In the view of Islam, the death penalty is justified in accordance with the texts contained in the al-Qur'an and Hadith. The threat of death penalty in Islam is known as Qishash (Makhrus 2009; Rokhmadi 2019). The death penalty in the Qur'an is stated in (Qaraati 1991):

a. QS. 2- Al-Baqarah 178 means: "Hey you who believe, it is obligatory for you to qishash with regard to those who are killed, free people with freedom, servants with servants and women with women. So whoever gets forgiveness from his brother should (who forgive) follow in a good way, and let (the person who is forgiven) pay (diat) to those who apologize in a good way (too). Such is a relief from your Lord and a grace. Whoever transcends the limit after that, it is for him a very painful torment" 
b. QS. 5- al-Maidah 33 means: "actually the punishment of people who fight against Allah and His Messenger and cause destruction on the earth, is only being killed, or crucified, or having their hands and feet cut off crossed, or exiled from their place of residence. That is an insult to them in the world and in the hereafter they will receive a great torment "

c. QS. 17- al-Isra '33 means: "And do not kill the soul that is haraam by Allah (kill it), but with a (reason) that is right. And whoever is killed by wrongdoing, then we have actually given power to the heirs, but the heirs do not go beyond the limit in killing. In fact, he is the one who gets help."

d. In the hadith Bukhari 3017, Nasa'i 4059 means: "Whoever changes his religion, kill him."

e. Hadith Bukhari 6878, Muslim 1676, Nasai 4016 means: "It is not lawful the blood of a Muslim who has testified there is no god but Allah and I (Muhammad) the messenger of Allah, except for three things, life is rewarded with life, people who commit adultery married, and people who leave their religion, separate themselves from the congregation of the Muslims.

Based on the text above, the death penalty in Islamic law includes: murder, robbery, subversion, adultery and religious treason (murtad) (Asmin 1995; Hanafi 1967; Praja 1995). However, if the crime is murder, then the perpetrator will receive forgiveness from the victim's family, namely having to pay diyat as compensation for the victim's family. The majority of Islamic religious leaders approve of the death penalty in Indonesia. The Regional Board of Nahdhatul Ulama (PWNU) for Central Java, KH. Ubaidillah Shodaqah (Gus Ubed) as Rais Syuriyah, is of the opinion that it is natural for Indonesia to apply the death penalty. According to him, the death penalty can be carried out on the basis of saving many dangers. Gus Ubed stated:

"Basically the verse 'walakum fil qishasi hayatun', meaning punishing that one (allowed) to save many in a state of danger, 
the danger is muhaqqaqah (real). Now the dangers of drugs are including the dangers of muhaqqaqah. For me, it is not because (reason) of the death of a drug user, but because it corrupts the morale of the drug user. If you die from the bandages it is not a problem, but before that it damaged morals, education and all aspects of community life because of drugs. If the dealer is sentenced to death, that's fine." According to him (Muryani and Rosyidah 2016i).

The leader of the al-Itqon Islamic boarding school really understands that no one should restrict the freedom of others. However, he said, because the freedom of that person violates the freedom of others, the perpetrator must have his freedom restricted as a form of punishment. According to this charismatic kiai, all of these punishments have the nature of restricting freedom, which means depriving them of human rights. However, Gus Ubed suggested that when implementing the death penalty, we must be very careful. This caution is the key in every legal process for death row inmates. The government is also very careful with the postponement of several executions and the long period of vulnerability until the death penalty is carried out. That means being given the opportunity, perhaps there is clemency or new evidence " (Muryani and Rosyidah 2016i).

A similar opinion was conveyed by Imam Munajat (Muhammadiyah Regional Board), fully supporting the state to impose the death penalty, he is sure that the plan will not be carried out carelessly without careful preparation and calculation. Imam also believes that the power over the death penalty is considered to be the authority of the state, and therefore it will certainly be implemented very carefully. If this has become a state regulation, it will be done very carefully. A person who does something also violates human rights, so he is subject to punishment because it also violates human rights" (Muryani and Rosyidah 2016e).

Ulama figures who joined the Indonesian Ulema Council (MUI) also agreed that the death penalty was lawful. Kiai Ma'ruf Amin in a press conference at the MUI building, in Jakarta, said that the death penalty does not contradict human rights and the 1945 Constitution. 
According to him, the death penalty is in accordance with the constitution (Hafsin 2011; Nurdin 2013). In the 1945 Constitution, human rights are not absolute but are limited by provisions such as law and others. It is feared that the substitution of the death penalty with imprisonment will encourage an increase in drug trafficking in the country and will increase the number of victims and the nation's worsening damage. In Islam, according to Ma'ruf Amin, the death penalty in certain cases is allowed for the benefit of the victim in order to get justice, restore public order and security, as well as create a deterrent effect. So MUI believes that the death penalty is very appropriate and appropriate for drug offenders. The MUI fatwa has stated the criteria with respect to the death penalty, the crime of killing human dignity, namely acts that have eliminated the function of reason. This decision is stated in the MUI fatwa number 53 of 2014 regarding penalties for producers, dealers, dealers and drug abuse. The MUI has issued a fatwa regarding the criteria for implementing the death penalty, such as murder perpetrators and drug dealer kingpins who deserve the death penalty. Either killing humans or killing human dignity is the same.

According to Sayyid Quthub in the interpretation of Fi Dzilalil Qur'an, argues that qishsash is not retribution for hurting and not to vent hurt feelings, but qishash is to ensure the continuity of life. The guarantee of survival in qishash comes from the cessation of the perpetrator's intention because he does not continue his actions due to fear of having to surrender his life to pay for the life of the person he kills (Sayyid 2000:294).

\section{Death Penalty in Catholic Perspective}

In Catholicism there are several verses that describe the death penalty. In Keluaran 21: 12-36 it states that:

Verse 12 : "Whoever hits a person to death must be put to death"

Verse 14 : "But if a person acts arrogantly towards others until he is kill him with trickery, then you must take mezhabku, so that he might die ". 
Verses 23-25: "But if the woman has an accident that brings death then you must give life for life, eye for eye, a leg for a leg, a blister for a scuff, a wound for a wound, for swelling swollen".

The death penalty, especially stoning was also imposed on those who did not keep the Sabbath holy. The death penalty for those who violate the prohibition of the Sabbath is mentioned many times in the Bible, as in Keluaran 31: 12-17, Keluaran 35: 1-3. The Sabbath is the seventh day sanctified by God, because God created the heavens and the earth for six days and on the seventh day God stopped working and rested. The death penalty in the form of stoning was also imposed for those who blasphemed the name of God as well as other death sentences for those who acted wrongly against others as mentioned in Imamat 24: 10-23. In this verse God warns people not to blaspheme His name, whoever blasphemes God's name must be put to death by stoning by the whole jemaat. In addition, people who worship idols are also punished by stoning, as stated in Ulangan 17: 2-7, that God forbids people from worshiping other Gods, bowing down to worship the sun, moon or the soldiers of heaven. If a human does this, he must be stoned or stoned to death.

In contrast to the above concept, Roman Catholics strongly oppose the death penalty, as well as the Catholic Church in Indonesia. Church Pastor St. Martinus, in Weleri Kendal, Father Raymundus Sugihartanto Pr, argues that the Catholic religious tradition does not justify the death penalty. According to him, the death penalty is prohibited in the guidelines of the Catholic Church itself, since 1995 the Pope has revoked the article in Catholic teachings that allows the death penalty, if there is a more humane punishment then that should be chosen, but he understands why the government enforces the death penalty. However, if there are other ways to protect people from inhuman things, then these other methods are preferable to the death penalty, because this method is considered to have more respect for one's dignity (Muryani and Rosyidah 2016g).

The same opinion as Sugihartanto, Pastor Aloys Budi Purnomo Pr, Chairman of the Commission for Interfaith Relations and 
Confidence of the Archdiocese of Semarang (KAS HAK Commission) also rejects the death penalty. He argued that the life and death of a person is in the hands of God, only God the creator of life, who has the authority when a person dies and when a person lives, that is the most fundamental (Muryani and Rosyidah 2016a).

A similar opinion by Pastor Antonius Benny Susetyo, Secretary of the Commission on Inter-Religious Relations and Beliefs of the Indonesian Bishops Conference (KWI), argues that the death penalty among the Catholic Church is a discourse theme that needs to be studied more deeply. The death penalty is still in a situation of controversy. During the reign of Susilo Bambang Yudoyono, he will already ratify the death penalty, considering whether to continue it or not. So that in the future it must be addressed wisely and applied to the dealer (drugs)" (Muryani and Rosyidah 2016c). Benny as a human rights activist said the death penalty was still pros and cons, but according to him, life sentence was more appropriate in Indonesia.

As a substitute solution for the death penalty, according to Pastor Siswintoko, is a life sentence as regulated in the Criminal Code of the Republic of Indonesia without pardon until the perpetrator dies without the intervention of the death penalty by anyone. No one has the right to lose the life of another person, including the state, the right to life is the most basic right given by the creator, therefore the Catholic Church always wants to defend life.

However, in the Bible there are several cases where the perpetrator is punishable by death, namely:

a. Kill (keluaran: 21:12)

b. Kidnapping (keluaran. 21:16)

c. Sex with animals (keluaran 22:19)

d. Adultery (Imamat 20:10)

e. Homosexual (Imamat 20:13)

f. Becoming a false prophet (Ulanangan 13: 5)

g. Prostitution and rape (Ulangan 22: 4)

Based on the things that are punishable by the death penalty, it indicates that the death penalty in the Catholic perspective is a 
recognized and legal punishment to be applied, although at the same time it does not always require the implementation of the death penalty. The validity of the death penalty from the biblical perspective is shown in (John 8: 1-11), in this provision Jesus showed grace when the death penalty should have been passed. Also in (Genesis 9: 6) it says "God is the one who decreed the death penalty: He who sheds human blood will have his blood spilled by man, because God made man in His own image.

\section{Death Penalty in Christian Perspective}

In the Bible are found several that describe the death penalty, such as in Keluaran 21: 21,14, 23-25. In Christian teachings, the death penalty, especially stoning is also imposed for those who do not keep the Sabbath holy. The death penalty for those who violate the prohibition of the Sabbath is mentioned in the Bible as (Keluaran 31: 12-17), (keluaran 35: 1-3). The Sabbath is the seventh day sanctified by God because God created the heavens and the earth for six days and on the seventh day God stopped working and rested. This concept is like in Catholic teaching.

According to Pastor (Pdt) Claodius Budhianto in the Christian tradition, the death penalty is actually not justified. The reason is that the right to take someone's life does not belong to humans, but it is God himself who has the right to take human life. According to him, there are no exceptions to punishment in Christianity, all crimes have the same value, so that no one crime is severely punished, while other crimes are lightly punished. All perpetrators of crimes must be punished, but not on the basis of the size or size of the crime (Muryani and Rosyidah 2016d).

According to the Indonesian Church Association (PGI), they do not agree with the death penalty because it is contrary to the essence of life. The views and attitudes of the PGI were also conveyed to the President of the Republic of Indonesia in the form of a letter signed by the General Chairperson of PGI, Pdt. Dr. Henriette T, Hutabarat Lebang and PGI General Secretary, Pdt. Gomar Gultom, M.Th. So PGI stated its stance: 
a. The death penalty tarnishes humanity and justice because it contradicts the essence of life given by God, and no longer leaves room for people to exercise self-improvement or repentance. Therefore PGI rejects the death penalty as a form of punishment for crimes.

b. So that the President of the Republic of Indonesia is wiser in reconsidering the execution. We pray that the President will consistently apply the NKRI constitution in the second principle of Pancasila, "a just and civilized humanity".

c. c. So that the President of the Republic of Indonesia as the head of state encourages the arrangement of regulations that still include the death penalty in it. PGI hopes that the death penalty sanction is removed in all regulations in accordance with the substance of our constitution article 28 I paragraph (1) of the 1945 Constitution.

d. We call on all Christians to pray for the President of the Republic of Indonesia, to be given wisdom and wisdom in responding to the implementation of the death penalty.

e. We pray that those who face execution will be given strength and fortitude in the face of the process that is about to take place (pgi.or.id).

\section{Death Penalty from Hindu Perspective}

In Hinduism, it is not stated whether the death penalty is permissible or not. However, it looks more at the level of severity and whether the crime is committed. In the Kutara Manawa Religion Book (the Majapahit Legislation Book) there are three types of crimes out of the eight types of crimes (asta lie) which, if committed, can be sentenced to death. Asta Dusta includes:

a. One who kills a person who doesn't lie;

b. Ordered to kill people without lying;

c. Harming people without sin;

d. Eat together with a killer;

e. As hustling as a killer;

f. Be friends with murderers;

g. Providing shelter against murderers; and 
h. Helping the killer.

In the eight asta of lies, three are sins of the soul and five are sins of property. Killing a person without sin, ordering to kill a person without sin, seriously injuring a person without sin, those are three sins. If the sins are proven by all three, the person must be put to death because these three sins must be paid with the soul. In the book Dharmasastra VIII: 359 it is explained that: "a non-Brahmin is threatened with the death penalty for committing adultery, because the wife of the four colors must be properly guarded.

With regard to the death penalty, the crime that deserves the death penalty is a person who has committed a cruel or serious crime. Referring to the Mahabbarata story, a person who can be sentenced to death is a person who commits a sin or crime repeatedly (recidivist). There are six crimes which are classified as cruel acts called sad atatayi. In the book of Slokantara 71: 32 states that: "people who burn houses, like to poison, witch doctors, murderers, rapists, traitors, these six belong to the Atatayi class". According to Hindu teachings, the death penalty is the maximum punishment and must see the quality of the crime.

"The opinion that disagrees or the sect of ahimsa is held by Mahatma Gandithe death penalty violates inherent human rights. There is no punishment that is carried out by means of violence or the loss of a person's life, so the death penalty can only be applied to certain crimes, such as terrorists who bombed buildings or areas where there were innocent people" (Muryani and Rosyidah 2016f).

For those who do not agree with the death penalty based on the Book of Santiparva in chapter 267 which tells of a prince who opposes the murder of the perpetrator of a crime that is always committed by a king who is his own father. However, Nyoman Surahatta as Chairperson of the Parisada Hindu Dharma Central Java agreed that if the act of murder was carried out in the framework of defending the country, such as killing enemies during the war and for perpetrators of severe punishment who carried out repeated or recidivist punishment, the death penalty could be applied. 
Although they do not clearly and clearly recognize the death penalty, there are differences of opinion among Hindu religious experts. In the Book of Manawa Dharmasastra VIII: 318 it is implied that there is a king's ability to sentence death and people who are sentenced to death will go to heaven because they are clean like those who have done good deeds.

The death penalty for followers of the Hindu religion, including "ngulah pati", because he already knew beforehand that his actions were evil, if later found guilty, he would receive a death penalty from the court. However, the death sentence decided by "humans" because they are considered "guilty", not necessarily in Sanghyang Widi's considerations he is also considered "guilty", such as victims of politics, riots and others.

\section{Buddhist Perspective Death Penalty}

Buddhist scriptures, in which textually it is not written about things that are subject to the death penalty, but in Buddhism is known about the Panca-sila. These five principles are the basic principles for Buddhists in developing their personalities so that they can behave well. Panca-sila contains five rules consisting of:

a. Prohibition against taking livesb;

b. The prohibition to stealc;

c. Prohibition of sexual harassmentd;

d. Don't speak harshlye; and

e. Prohibition of drinking liquor.

Buddhism does not recognize the death penalty, but in it is found the teaching of cause and effect or what is called the law of karma. The law of karma is the law of the cause and effect of actions, if someone does good then the pleasant state will be accepted and vice versa, if a person does evil then an unpleasant state will be obtained. The provisions of the law of karma are found in Samyutta Nikaya I: 227, the Buddha said: "According to the seed that has been sown, that is the fruit he will reap. The maker of good will get good, the maker of evil will also get evil. Sow the seeds and you will taste the fruits from them". 
The head of the Persada Buddhist Dharma Sect for the Central Java Region, Romo Hadi, said that the death penalty is against the teachings of Buddhism. According to him, in Buddhism it is known as the karmic system, don't kill or take someone's life away, hurting anyone in his teachings is not allowed. The ideal punishment for perpetrators of serious crimes is life sentence, death and life in Buddhist teachings cannot be requested, therefore the death penalty is not appropriate if applied in Indonesia. The principle of Buddhism is how humans can keep their children from being pure (Muryani and Rosyidah 2016h).

In the Buddhist teaching book, Dhammapada there is an article related to the death penalty, namely article 10: "Everyone is afraid of punishment, everyone is afraid of death, as you also feel. So don't kill or cause murder. Everyone is afraid of punishment; everyone loves life as you feel it too. So don't you kill or cause murder."

The existence of these articles by Buddhists is used as a basis for opposing the existence of the death penalty. However, in Thailand, Myanmar, Sri Lanka, Japan, as a country where the majority of the population is Buddhist, they apply the death penalty as a type of crime.

\section{Death Penalty from Confucian Perspective}

Kong $\mathrm{Hu} \mathrm{Cu}$ religion, basically does not recognize the death penalty, according to its teachings all humans are basically born into the world carrying their nature as beings that are essentially good or true character (xing). Xing is a seed that must be grown and developed into love. To develop xing in order to develop and become a human being as a perfect being, then humans must always be on the path of truth (the holy path). Therefore humans need guidance so that humans live in the path of truth. This guidance to the path of truth is called Religion. A person who adheres to the Confucian religion must follow predetermined obligations (Zarkasi 2014:27), namely:

a. Believe in One Godhead;

b. Believe that his life (by and) carry the word of God; 
c. Believe that the word of God is a sacred task that must be accounted for and at the same time a gift and ability in his life;

d. Believe that religion is a gift of guidance from God Almighty to develop oneself along the path of truth (holy);

e. Believing that loyalty promotes virtue must be practiced by loving, patronizing fellow humans, fellow creatures and loving the environment;

f. Believe that the sacred obligation is to promote goodness and practice it to the peak of goodness; and

g. Believing that virtue is the way of salvation, the highest happiness in human dignity as the noblest creature created by God.

This obligation must be carried out responsibly by followers of Confucianism so that he is able to humanize himself as a human, by developing the seeds of virtue that already exist in his true character which include the qualities of Jien (love), Yong and Gie (dare to uphold truth, being able to distinguish between right and wrong), Lee (decency/knowing order and law), $\mathrm{Ti}$ (wisdom) and Sien (sincere/trustworthy) (Zarkasi 2014:27-28).

Secretary of Semarang City MATAKIN Andi Gunawan said: the death penalty in the Confucian religion is not taught, but in its teachings it recognizes human love. Therefore, from a human perspective, the death penalty should not be carried out because it is considered contrary to the teachings of the Confucian religion, namely the existence of love.

According to this interfaith activist who is part of the Forum for Religious Harmony (FKUB) in Central Java, everything must be reviewed that in Confucian teachings, life and death are noble words, because noble words must be returned to God. Therefore, talking about life and death is the area of God's word. God is in the Confucian religion as a human nature, which consists of four characteristics, namely: love, truth, morality and wisdom (Muryani and Rosyidah 2016b). 
Andi emphasized that the death penalty was allowed if the perpetrator made mistakes repeatedly. If someone has done something wrong, it must be straightened out, but if it is still not corrected many times, then it must be executed. "We will be sad if we see in the future our children or our generation are damaged by drugs, and then the death penalty is a policy. In Confucianism, in pure teaching, there is nothing that discusses the death penalty, but the basis starts from the teaching that when someone is wrong they must be corrected. However, if what is crooked is straightened it is still crooked; it means that it has violated the truth" (Muryani and Rosyidah 2016b).

Based on this statement, in fact Confucianism allows the death penalty as a type of punishment that can be applied in certain crimes, as a last resort.

\section{The Concept of the Death Penalty in the Perspective of Pancasila}

Pancasila is the basis of the state of a nation which functions as a philosophical foundation, contains basic values, norms and ideals that the adherents of society want to realize in the life of society, nation and state, therefore:

a. Pancasila is the basis, base of departure, principle or foundation for all activities in the life of the community, nation and state. As is well known, Pancasila comes from the values that develop and live in Indonesian society.

b. Pancasila is a director or regulator and controller in the life of society, nation and state in the form of norms or rules that must be obeyed so that the direction to achieve goals or objectives does not deviate. In this context, Pancasila is the "source of all sources of law", so that all laws and regulations that exist in the Unitary State of the Republic of Indonesia may not conflict with the values contained in Pancasila.

c. Pancasila is the goal of all activities in the life of society, nation and state. The aim of Pancasila as the goal of society, nation and state is stated in the Preamble of the 1945 Constitution (Soejadi 1999). 
The sila of the One Godhead are the precepts that provide a spiritual foundation for all Indonesian people to embrace a religion according to their beliefs. Religious adherents have the right to carry out their religious teachings with guarantees from the state. State and religion have a close relationship. The relationship between the state and religion based on Pancasila can be detailed as follows (Kaelan 2012:215-216):

a. The country is based on the One Godhead;

b. As a Godly nation, every citizen has the human right to embrace and practice worship according to their respective religions;

c. Tolerate other people in practicing religion in the country;

d. All aspects in implementing and administering the state must be in accordance with the values of one Godhead, especially positive legal norms and moral norms, both religious and moral.

With regard to the institutionalization of the death penalty in Indonesia, from the perspective of the first precept, it can be explained that Pancasila provides guarantee and protection for all religions, has freedom and has strong protection to carry out its religious teachings. So, the existence of the death penalty in religious teachings is guaranteed by Pancasila. The guarantee of protection against the existence of the death penalty in religious teachings is getting stronger if the death penalty is stated in the prevailing laws and regulations.

According to Muhammad Hatta, the precepts of the One and Only Godhead lead the ideals of the state to organize everything that is good for the people and society (Hamzah and Sumangelipu 1984:70). Based on this statement, all laws including the application of the death penalty must be based on divine values. The value of the One and Only Godhead must be a basic value that is included in national law, so that the value of the One Godhead is a central value and animates other values. This implies that national law recognizes the existence of God. 
Just and Civilized Humanitarian Principles are encapsulated by the value of one degree, equal obligations and rights, mutual love, mutual respect, courage to defend truth and justice, tolerance and the value of mutual cooperation. Based on this principle, every human being has the same position, rights and obligations. Everyone must be treated according to the basic values as God's most glorious creature. This Just and Civilized Humanitarian Precept is an acknowledgment of human rights. Therefore, arbitrary attitudes and behavior towards others are actions that are not in line with fair and civilized human values. The enforcement of humanitarian values must be enforced through consistent and accountable law enforcement by various means including the use of the death penalty as a law enforcement tool that can be used to prevent actions beyond humanitarian boundaries for the realization of the ideals of Indonesian society.

The manifestation of fair and civilized human values is set forth in the 1945 Constitution starting from articles 28 to 28J. Article 28A states that every person has the right to live and has the right to defend his life, the provisions of this article are supported by Article 28 I that the right to life, the right not to be tortured, the right to freedom of thought and conscience, the right to religion, the right not to be enslaved, the right to be recognized. as a person before the law and the right not to be prosecuted on the basis of retroactive law are human rights that cannot be reduced under any circumstances (Ekaputra and Kahir 2010; Moeljatno 2002; Muladi and Arief 1984; Waluyo 2000).

This means that in fact the right to life, the right not to be tortured, the right not to be prosecuted by retroactive law as stated in Article $28 \mathrm{I}$ is limited and can be limited by law, so that the existence of the death penalty is one of the protections and guarantees of the fulfillment of basic human rights. Finally, the basic human rights are not taken away by others. Anyone who deprives another person's basic rights can be subject to law in accordance with the prevailing laws and regulations.

The principles of unity of Indonesia contain national values, love the homeland and are willing to sacrifice for the sake of the nation 
and state, although they have different features, because Indonesia is a country that upholds differences in ethnicity, religion, race with the motto of Bhinneka Tunggal Ika. The Principle of Unity of Indonesia is a way to foster an attitude of people who love the homeland, nation and state of Indonesia, participate in fighting for their interests and are loyal to fellow citizens, placing Indonesian people in unity, integrity, and the interests and safety of the nation and state above personal interests and group (Ali 2002; Sholehuddin 2003).

Based on these philosophical values, even though Indonesia has different ethnicities, religions and races, unity and unity are the main pillars that must be upheld, by placing the interests of the state and the nation above personal and group interests. Cultivating a selfsacrificing attitude in the interests of the state and nation is very important, so a sense of nationalism and Indonesian homeland is developed in order to maintain order. Public order must be created to ensure unity and association. So that the existence of the death penalty aims to create public order and create a sense of security for the entire nation. Therefore, the existence of the death penalty does not contradict the third principle and is instead an implementation of the Pancasila values to safeguard the diversity of ethnicities, religions and races in Indonesia which is based on the principle of Bhinneka Tunggal Ika.

The fourth principle of democracy led by wisdom in deliberation/representation implies that the value of sovereignty is in the hands of the people (democracy) and does not impose the will on others. The people have an important role in building the country by upholding the interests of the state or nation while respecting personal interests. The populist precepts contain values to create a just government with a sense of responsibility (Simanjuntak 2020).

The principles of a democratic state as stated in the fourth principle are contained in Article 1 paragraph 2 of the 1945 Constitution which emphasizes that Indonesian democracy adheres to two principles, namely people's sovereignty (democracy) and nomocracy (rule of law). Based on this, Indonesia is a country that adheres to a democratic system that places law as a pillar of the state. 
The people are the holders of sovereignty who have the right to make decisions and the law is used as a tool to resolve things that can harm democracy. Democratic and nomocratic systems must operate in a balanced manner.

Every decision taken must be accountable morally to One Godhead by upholding human dignity and the values of truth and justice. The institutionalization of death penalty is a collective agreement resulting from a democratic process and decision making in accordance with the fourth precept. Thus the application or institutionalization of death penalty in several crimes set forth in the prevailing laws and regulations is actually the application of the fourth precept. The institutionalization of death penalty is not intended as a tool to oppress humans and shackle democracy, but rather as a tool to control community behavior that can injure and damage the joints of the life of the nation and state.

Sila of social justice for all Indonesian people contain the values of a fair attitude, respect for people's rights and an attitude of mutual cooperation which ensures the prosperity of society as a whole and fairly. As for justice, it is divided into several types:

a. Communicative Justice is a justice that gives each person what they are part of based on a person's right to a particular object.

b. Distributive Justice is a justice that gives to each of what constitutes a right on the subject of rights, namely the individual. It means justice which assesses from proportionality based on services, needs and abilities.

c. Legal Justice is justice according to law whose object is the community protected by law for the common good.

d. Vindicative Justice is a justice that provides punishment or a fine in accordance with the offense or crime.

e. Creative Justice is a justice that gives each person based on their share in the form of freedom to be able to create their creativity in various fields of life.

f. Protective Justice is justice by providing a guard or protection to individuals from an arbitrary action by another party. 
Based on this understanding and type of justice, especially legal judgments, indicative justice and protective justice, the existence of the death penalty in Indonesia as stipulated in statutory regulations is one of the ways to achieve justice. The death penalty is intended to bring out the common good so that there is no oppression. Based on this concept, the existence of the death penalty can be accounted for in the Pancasila state, which is manifested as the protection of individuals and society for the creation of justice and truth in law based on One Godhead (Poernomo 1982:17).

Pancasila as a value system has an abstract existence, invisible to the eye, but its existence and role can be captured with the heart's eye. If Pancasila is separated from the national law, then the national law will die, if the national law exists only as a zoombi (living corpse) which is frightening, damaging and disturbing the comfort of human life and life (Atmoredjo 2009:16).

Pancasila as a guideline for state and legal life in Indonesia must be concrete and not just an abstract ideal. In this case, according to Notonegoro, quoted by Soejadi, it provides an affirmation that Pancasila is not just an aspiration, but has a formal and material form and content to serve as a guideline for concrete life in the state and Indonesian law (Soejadi 1999:89). Therefore, the institutionalization of the death penalty in Indonesia is an option for legal sanctions that will restore legal preservation in accordance with Pancasila.

\section{Conclusion}

Based on the description above, it can be concluded that:

The concept of the death penalty in the perspective of official religions in Indonesia as contained in the respective holy books: In Islamic teachings, there are several verses that explain the validity of the death penalty, such as in surah al-Baqarah 178, al-Maidah: 33, alIsra' 33. In Hadith Bukhori 3017, 68878, Muslim 1676 and Nasa'I 4016, 4059; In Christian teachings there are several verses that describe the death penalty, such as in Imamat 21: 12-36, Ulangan 17: 2-7; In Hinduism, there are teachings contained in the Kutara 
Manawa Religion book (Majapahit statutory book), there are three types of crime out of eight types of crime (asta lie) which, if committed by someone, can be sentenced to death, namely killing people without sin, ordering to kill people without sin, seriously injuring a sinless person, those are all three sins. If their sins are proven, the three of them must be put to death because these three sins must be paid with the soul. Likewise, people who commit serious crimes and crimes that are committed repeatedly (recidivists) are also entitled to the death penalty, referring to the book of Slokantara 71:32; In the Buddhist scriptures textually it is not written about things that are subject to the death penalty, but it is known as the Panca-sila which includes the prohibition against taking one's life, the prohibition on stealing, the prohibition of sexual harassment, the prohibition on speaking harshly and the prohibition of drinking alcohol. Although there is no death penalty known, in Buddhism there is a teaching of cause and effect or known as the law of karma as stated in Samyutta Nikaya 1: 227; In the Confucian religion there is no death penalty, according to him all human beings are basically born into the world carrying their nature as beings that are essentially good or their true character (xing). In the Confucian teachings, if someone makes a mistake, it must be straightened out, but if it is corrected many times, it still cannot, then the death penalty can be applied as a last resort.

The concept of the death penalty in terms of the basic state perspective Pancasila can be explained that Pancasila is a national principle that functions as the philosophical foundation of the nation. The institutionalization of the death penalty in Indonesia from the perspective of the first principle can be explained that Pancasila provides guarantee and protection for all religions. All religions have freedom and get strong protection to carry out their religious teachings. Likewise, the existence of the death penalty in religious teachings is guaranteed by Pancasila. This guarantee is even stronger if the death penalty is stipulated in the prevailing laws and regulations.

Based on the second principle, every human being has the same position, rights and obligations. This Just and Civilized Humanitarian Precept is an acknowledgment of human rights. Humans must be recognized and treated in accordance with their dignity and status as 
creatures of God Almighty who are equal in rank, have the same rights and basic obligations. Upholding human values must be enforced through consistent law enforcement with various means Maria Anna Muryani and Noor Rosyidah, The Concept of Death Penalty

including the use of the death penalty as a law enforcement tool that can be used to prevent acts beyond humanitarian boundaries for the realization of the ideals of the Indonesian socialism community.

The Principles of Unity of Indonesia contain philosophical values of nationalism, love for the country and are willing to sacrifice for the sake of the nation and state, even though they have different features. Indonesia is a country that upholds differences in ethnicity, religion and race with the motto Bhinneka Tungal Ika. The established laws must be obeyed. The existence of the death penalty actually aims to create public order and create a sense of security for the entire nation. Therefore, the existence of the death penalty does not contradict the third principle and is even an implementation of the Pancasila values to safeguard the diversity of ethnicities, religions and races in Indonesia which is based on the principle of Bhinneka Tunggal Ika.

Based on the fourth principle, the death penalty does not contradict democratic (populist) values and nomocratic values, because it is set forth in laws and regulations agreed upon by the people. The institutionalization of the death penalty is not intended as a tool to oppress humans and shackle democracy as a tool to control community behavior that can injure and damage the joints of the life of the nation and state. The principle of social justice for all Indonesian people contain the values of a fair attitude, respect for the rights of others and an attitude of mutual cooperation, which ensures the prosperity of society as a whole and fairly. The existence of the death penalty in Indonesia as stipulated in the laws and regulations is one way to achieve justice. So the institutionalization of the death penalty in Indonesia is an option for legal sanctions that will restore legal preservation in accordance with Pancasila. [w] 


\section{References}

Ali, Achmad. 2002. Menguak Tabir Hukum, Suatu Kajian Filosofis Dan Sosiologis. Jakarta: Candra Pratama.

Arief, Barda Nawawi. 2005. Bunga Rampai Kebijakan Hukum Pidana. Bandung: Citra Aditya Bakti.

Asmin, Yudian W. 1995. Filsafat Hukum Islam Dan Perubahan Sosial Judul Asli: Islamic Legal Philosify: A Study of Abu Ishaq Al Shatibi's Lifw and Thought. Surabaya: Al-Ikhlas.

Atmoredjo, Sudjito Bin. 2009. "Negara Hukum Dalam Perspektif Pancasila." Makalah Untuk Kongres Pancasila, Kerjasama Mahkamah Konstitusi RI Dan Gadjah Mada, Tanggal 30:31.

Darsono, P. 2006. Karl Marx: Ekonomi Politik Dan Aksi Revolusi. Diadit Media.

Ekaputra, Muhammad and Abdul Kahir. 2010. Sistem Pidana Di

Dalam KUHP Dan Pengaturannya Menurut Konsep KUHP Baru. Medan: USUpress.

Gilessen, John. 2005. Sejarah Hukum Dalam Suatu Pengantar. Bandung: Refika Aditama.

Hafsin, Abu. 2011. "Pidana Mati Bagi Koruptor." Justisia.

Hamzah, Andi and A. Sumangelipu. 1984. Pidana Mati Di Indonesia;

Di Masa Lalu, Kini Dan Di Masa Depan. Jakarta: Ghalia Indonesia.

Hanafi, Ahmad. 1967. Asas-Asas Hukum Pidana Islam. Jakarta: Bulan Bintang.

Hapsin, Abu. 2017. "Religious Freedom and the Idea of Establishing Islamic State." Walisongo: Jurnal Penelitian Sosial Keagamaan 25(1):63-90.

Kaelan. 2012. Problem Epistemologis Empat Pilar Berbangsa Dan Bernegara. Yogyakarta: Paradigma.

Makhrus, Munajat. 2009. Hukum Pidana Islam Di Indonesia. Yogyakarta: Teras.

Moeljatno. 2002. Asas-Asas Hukum Pidana. Jakarta: Rineka Cipta. Muladi and Barda Nawawi Arief. 1984. Teori-Teori Dan Kebijakan Pidana. Bandung: Alumni.

Muryani, Maria Anna and Noor Rosyidah. 2016a. "Interview with 
Aloys Budi Purnomo Pr, 12 Juni 2016."

Muryani, Maria Anna and Noor Rosyidah. 2016b. "Interview with Andi Gunawan, 18 Mei 2016."

Muryani, Maria Anna and Noor Rosyidah. 2016c. "Interview with Benny Susetyo, 13 Juni 2016.”

Muryani, Maria Anna and Noor Rosyidah. 2016d. "Interview with Claodius Budhianto, 18 Mei 2016."

Muryani, Maria Anna and Noor Rosyidah. 2016e. "Interview with Imam Munajat on 11 Juni 2016."

Muryani, Maria Anna and Noor Rosyidah. 2016f. "Interview with Nyoman Surahatta, 2 Mei 2016."

Muryani, Maria Anna and Noor Rosyidah. 2016g. "Interview with Raymundus Sugihartanto Pr, 27 Mei 2016.”

Muryani, Maria Anna and Noor Rosyidah. 2016h. "Interview with Romo Hadi, 27 April 2016."

Muryani, Maria Anna and Noor Rosyidah. 2016i. "Interview with Ubaidillah Shodaqah on May 14, 2016."

Nawawi Arief, Barda. 2009. Tujuan Dan Pedoman Pemidanaan. Semarang: Badan Penerbit Universitas Diponegoro.

Nurdin, Nazar. 2013. "Hukuman Mati Bagi Koruptor (Studi Analisis Fatwa NU Tentang Hukuman Mati Bagi Koruptor)."

Poernomo, Bambang. 1982. Hukum Pidana Kumpulan Karangan Ilmiah. Jakarta: Bina Aksara.

Praja, Juhaya S. 1995. Filsafat Hukum Islam. Bandung: Pusat Penerbitan Universitas.

Prakoso, Djoko and Nurwachid. 1984. Studi Tentang PendapatPendapat Mengenai Efektivitas Pidana Mati Di Indonesia Dewasa Ini. Jakarta: Ghalia Indonesia.

Qaraati, Muchsin. 1991. Al-Qur'an Menjawab Dilema Keadilan. Jakarta: Firdaus.

Rokhmadi. 2019. Kritik Konstruksi Hukum Pidana Islam. 1st ed. edited by N. Nurdin. Semarang: ELSA Press.

Salmi, Akhiar. 1985. Eksistensi Hukuman Mati. Jakarta: Aksara Persada Press.

Sayyid, Quthb. 2000. Tafsir Fi Zhilalil Qur'an. Jakarta: Gema Insani Press. 
Septiawan, Yudha Nugraha. 2020. "Analysis of the Causes of Narcotics Recidivities in Class IIa Prisons in Bogor." Walisongo Law Review (Walrev) 2(1).

Sholehuddin, Muhammad. 2003. Sistem Sanksi Dalam Hukum Pidana: Ide Dasar Double Track System \& Implementasinya. Jakarta: RajaGrafindo Persada.

Simanjuntak, Efendi Lod. 2020. "Incoming Extradition in Indonesia and Its Implication to Human Rights." Walisongo Law Review (Walrev) 1(2).

Siswanto, Arie. 2009. "Pidana Mati Dalam Perspektif Hukum Internasional." Refleksi Hukum.

Soejadi. 1999. Pancasila Sebagai Sumber Tertib Hukum Indonesia. Yogyakarta: Lukman Offset.

Waluyo, Bambang. 2000. Pidana Dan Pemidanaan. Jakarta: Sinar grafika.

Zakaria, Moch Subhan. 2020. "Implementation of the Methadone Maintenance Therapy Program for Highrisk Drug Prisoners." Walisongo Law Review (Walrev) 2(1).

Zarkasi, Ahmad. 2014. "Mengenal Pokok-Pokok Ajaran Kong Hucu." Al-Adyan: Jurnal Studi Lintas Agama 9(1):21-35. 